\title{
PENGEMBANGAN DESA WISATA BERBASIS PEMBERDAYAAN MASYARAKAT DESA WISATA KAKI LANGIT PADUKUHAN MANGUNAN
}

\author{
Anggit Kurnia Prihasta \\ Ilmu Pemerintahan, Universitas Muhammadiyah Yogyakarta \\ Email: anggitprihasta@gmail.com \\ Suswanta \\ Ilmu Pemerintahan, Universitas Muhammadiyah Yogyakarta \\ Email: soes_umy@yahoo.com
}

\begin{abstract}
Local tourism is currently developed such as Tourism Village development. Kaki Langit Tourism Village one of the tourism village that is currently developing and as a tourism village of Bantul Regency and special region of Yogyakarta. Kaki Langit Tourism Village uses the concept of community empowerment around Padukuhan Mangunan in which the tourism village stands. The natural beauty, cultural diversity, traditions and potential of the community have been the drive of the thriving Kaki Langit Tourism Village. Kaki Langit Tourism Village is developing. The community develops traditional culinary tourism, the lodging of Javanese rural concept, outbound tourism, and nature tourism. With the community being included directly today the community feels the impact of the economy with the additional income they can. This research uses qualitative descriptive methods. The result is that local tourism through the development of tourism village with Community Empowerment is able to bring economic impact to the community.
\end{abstract}

Keywords: Development of tourist village, community empowerment, and economic impact

\section{Pendahuluan}

Pengembangan pariwisata pada saat ini menjadi salah satu pembangunan prioritas oleh pemerintah pusat maupun daerah. Seperti yang dikatakan oleh Fandi, Zauhar, \& Hermawan (2012) bahwasannya pariwisata menjadi hal penting untuk dikembangkan oleh suatu negara melalui pemerintah daerah, karena dengan 
pengembangan wisata mampu menggali potensi yang dimiliki oleh suatu daerah itu sendiri (Fandi, Zauhar and Hermawan, 2012). Pembangunan pariwisata pada saat ini telah banyak dilakukan oleh pemerintah daerah untuk mengembangkan dan melestarikan potensi wisata yang ada di daerah tersebut. Karena sektor pariwisata pada saat ini menjadi salah satu sektor yang memiliki kontribusi besar. Seperti yang dikakatan oleh Zaenuri (2018) bahwasannya sektor pariwisata menjadi sektor penting dalam kontribusinya pada pendapatan nasional, selain itu sektor wisata dapat menjadi alternatif untuk membuka lapangan kerja baru bagi masyarakat (Zaenuri, 2018).

Pembangunan di sektor wisata ini bersifat inklusif dimana mampu melibatkan masyarakat sebanyak-banyaknya dalam rangka peningkatan perekonomian masyarakat (Kristiana and Theodora, 2016). Hal itu dituangkan dalam sasaran pembangunan pariwisata tahun 2019 oleh Kementerian Perencanaan dan Pembangunan Nasional / Badan Perencanaan dan Pembangunan Nasional (BAPPENAS). Tujuan dari sasaran pembangunan pariwisata inklusif yakni meningkatkan usaha lokal dalam perindustrian pariwisata dan meningkatkan jumlah tenaga kerja lokal. Dengan cara ini pemerintah juga berupaya untuk mengurangi tingkat kemiskinan masyarakat, pengangguran, dan diskriminasi gender dalam keterlibatan proses pembangunan di sektor pariwisata. Pada tahun 2015 Kementerian Pariwisata pada Laporan Akuntabilitas Kinerja Instansi Pemerintah (LAKIP) mencatatkan bahwa kegiatan pariwisata pada tahun 2015 memberikan dampak positif terhadap pertumbuhan Produk Domestik Bruto (PDB) tahun 2015 sebesar Rp. 461,36 Triliun, atau 4,23 \% dari PDB nasional. Pencapaian PDB dalam sektor pariwisata tersebut dari pengeluaran yang dilakukan oleh wisatawan lokal maupun mancanegara, pengeluaran anggaran pemerintah, dan berbagai pergerakan investasi yang berkembang pada kegiatan pariwisata. Hal tersebut membuktikan bahwa kegiatan pariwisata menyumbang cukup besar untuk pendapatan negara. 
Aktivitas atau kegiatan pengembangan pariwisata lokal melalui desa wisata merupakan salah satu cara pemerintah untuk mengurangi kemiskinan dan melestarikan potensi desa yang dapat dikembangkan. Karakteristik desa wisata memiliki konsep suatu bentuk integrasi antara atraksi, akomodasi, dan pemenuhan fasilitas pendukung dalam suatu struktur masyarakat yang menyatu dengan tata cara dan tradisi yang sudah ada dan berlaku (Muhammad Farid Ma'ruf and Kurniawan, 2017). Pengembangan desa wisata merupakan kegiatan alternative pariwisata yang didasarkan adanya potensi yang dimiliki di desa dengan aspek kelestarian lingkungan, tradisi yang sudah ada sejak dahulu, kebudayaan yang melekat pada masyarakatnya dan fokus dalam memberdayakan masyarakat di sekitar desa (Dwiridhotjahjono, Wibowo and Nuryananda, 2019). Adanya keikutsertaan masyarakat dalam pengembangan desa wisata dapat menciptakan iklim pariwisata yang berkelanjutan tidak hanya pengembangan wisata untuk perekonomian tapi juga melestarikan apa yang sudah ada sebelumnya. Oleh karena itu saat ini pemerintah menggencarkan pengembangan pariwisata lokal dengan konsep desa wisata untuk memberdayakan, meningkatkan perekonomian, dan melestarikan budaya masyarakat lokal.

Salah satu pemerintah daerah yang sedang mengembangkan pariwisata lokal desa wisata yakni Pemerintah Daerah Daerah Istimewa Yogyakarta (DIY) yang dikenal dengan berbagai keankeragaman alam dan budayanya sampai dengan tahun 2018 menurut data Laporan Statistik Pariwisata DIY tahun 2018 telah memiliki 60 desa wisata yang tersebar di empat kabupaten, salah satu kabupatennya yakni Kabupaten Bantul memililki 21 desa wisata. Kabupaten Bantul yang memiliki inisiasi untuk membangun wilayahnya dimulai dari tingkat desa yang memiliki julukan "Makaryo Mbangun Desa" yang memiliki arti bekerja membangun desa dan memiliki tujuan untuk meningkatkan pembangunan dan kesejahteraan masyarakat Kabupaten Bantul yang diawali dengan membangun dari tingkat pedesaan. Kabupaten Bantul memiliki luas 506,85 $\mathrm{km}_{2}$ serta memiliki topografi berupa perbukitan serta berhadapan 
langsung dengan samudera hindia. Hal tersebut membuat Kabupaten Bantul memiliki keanekaragaman hayati dan kebudayaan maupun tradisi yang dapat menjadikan potensi pariwisata, salah satunya desa wisata.

Desa Wisata Kaki Langit merupakan salah satu desa wisata yang menjadi percontohan desa wisata di Kabupaten Bantul bahkan di DIY. Letak desa wisata ini yang sangat strategis yang berada di perbukitan dengan ketinggian 320 mdpl yang berada di Padukuhan Mangunan, Desa Mangunan, Kecamatan Dlingo. Dengan keadaan topografi tersebut tak heran jika kawasan Desa Mangunan berupa perbukitan yang masih asri. Desa Wisata Kaki Langit mulai dirintis pada pertengahan tahun 2014 dengan mengikutsertakan masyarakat sekitar secara langsung dalam mengembangkan dan mengelola kegiatan desa wisata. Destinasi di Kawasan Mangunan yang masuk dalam Desa Wisata Kaki Langit antara lain seperti: hutan pinus, kebun buah, tebing watu lawing, rumah hobbit, potensi wisata kuliner tradisional, dan penginapan yang memiliki nuansa pedesaan khas jawa. Potensi yang dimiliki menarik wisatawan untuk berkunjung dan menginap sehingga semakin ramai didatangi wisatawan pada akhir pekan dan liburan. dari adanya kegiatan desa wisata dengan mengikutsertakan masyarakat secara langsung maka salah satu dampak yang diraskaan yakni dampak perekonomian dimana masyarakat mendapatkan penghasilan tambahan disamping profesi utamanya. Tak heran jika desa wisata ini sudah banyak mendapat penghargaan tingkat kabupaten, provinsi, sampai nasional.

Berdasarkan uraian latar belakang masalah tersebut, dalam penelitian ini berfokus pada bagaimana pengembangan Desa Wisata Kaki Langit yang dilakukan oleh masyarakat secara langsung sehingga masyarakat merasakan dampak perekonomian dari adanya desa wisata. 
Pengembangan Desa Wisata Berbasis Pemberdayaan Masyarakat Desa Wisata Kaki Langit...

\section{Kerangka Pikir}

\section{Pengembangan Desa Wisata}

Desa wisata merupakan salah satu bentuk pengembangan yang masuk dalam kegiatan pariwisata alternatif dimana proses pembangunannya memperhatikan keberlanjutan yang ada di dalam desa tersebut seperti: tradisi, kebudayaan, dan ciri khas. Desa wisata menjawab tentang kebutuhan gaya hidup masyarakat saat ini dan banyak disukai. Pengembangan desa wisata yang dikelola oleh masyarakat lokal yang hakikatnya masayarakat setempat merupakan salah satu faktor penting, karena masyarakat setempat yang memahami dan mengetahui lebih dalam desa wisata tersebut.

Dalam pengembangan desa wisata perlu dipahami kriterianya antara lain: 1) Adanya obyek atau destinasi dan daya tarik: desa memiliki destinasi wisata dan lokasinya berdekatan dengan obyek wisata yang sudah terkenal agar dapat masuk dalam paket perjalanan; 2). Adanya akses fisik (fasilitas) dan pemasaran; 3). Memiliki potensi kemitraan; 4). Adanya antusiasme dan motivasi masyarakat; dan 5). Tersedianya fasilitas umum. Selain itu pengembangan desa wisata juga harus memperhatikan prinsip perencanaan desa wisata amtara lain: 1). Memperhatikan karakteristik lingkungan setempat; 2). Meminimalisir dampak negatif yang akan ditimbulkan di kawasan tersebut; 3). Materi yang digunakan sesuai dengan keadaan lingkungan setempat; 4) bahan-bahan yang digunakan ramah lingkungan dan dapat di daur ulang; 5). Melibatkan masyarakat setempat atau lokal dalam pengembangan baik secara langsung maupun tidak langsung (Arida and Pujani, 2017).

\section{Pemberdayaan Masyarakat}

Undang-Undang Nomor 6 Tahun 2014 tentang Desa dalam pasal 1 ayat (12) menjelaskan bahwa upaya mengembangkan masyarakat dengan pengembangan kemandirian dan kesejahteraan dengan meningkatkan pengetahuan dan kompetensi 
masyarakat. Sedangkan menurut Ganjar Kartasasmita menerangkan bahwa konsep pemberdayaan masayarakat merupakan salah satu strategi pembangunan kerakyatan (Indardi, 2016).

Upaya pemberdayaan ke masyarakat dengan menekankan variasi lokal sangat cocok untuk masyarakat pedesaan yang sudah memiliki potensi masing-masing serta memiliki keunikan untuk melestarikan budaya (Indardi, 2016). Masyarakat pedesaan sudah memiliki identitas atau tradisi yang biasa dilakukan, berasal dari nenek moyang atau leluhur yang berada di desa tersebut. Masyarakat pedesaan meneruskan dan melestarikan tradisi dan budaya yang sudah ada sebelumnya sebagian besar berupa ucapan rasa syukur kepada Tuhan Yang Maha Esa ataupun acara saral lainnya yang biasa mereka lakukan.

\section{Dampak Perekonomian}

Kegiatan pariwisata khususnya pariwisata lokal seperti desa wisata salah satu kegiatan yang mampu menghasilkan pertumbuhan perekonomian yang signifikan. Hal tersebut seperti terciptanya lapangan kerja baru dengan adanya usaha-usaha baru yang dirintis masyarakat, peningkatan standar hidup masayarakat sekitar, dan meningkatnya tingkat produktivitas masyarakat lokal. Selain itu kegiatan pariwisata lokal desa wisata juga mampu menambah Pendapat Asli Desa (PADes) dengan adanya retribusi yang diterima dari adanya kegiatan pariwisata tersebut.

Pitana (2009) mengemukakan bahwa jumlah wisatawan yang berkunjung ke sebuah tempat wisata banyak, dapat meninggalkan dampak yang positif maupun negatif khususnya dampak ekonomi (Hermawan, 2016). Pitana (2009) berpendapat bahwa dampak dari adanya kegiatan pariwisata terhadap kondisi ekonomi dapat dikategorikan menjadi 7 kategori antara lain: 
1) Dampak penerimaan devisa

2) Dampak pendapatan masyarakat

3) Dampak kesempatan kerja

4) Dampak distribusi manfaat atau keuntungan

5) Dampak kepemilikan dan kontrol (ekonomi) masyarakat

6) Dampak pembangunan

7) Dampak pendapatan pemerintah

Dari uraian kategori yang dikemukakan diatas, yang lingkupnya sesuai dengan penelitian ini yaitu pariwisata lokal desa wisata maka tidak terpaku secara keseluruhan 7 kategori. Kategori yang tidak dikaji yakni dampak penerimaan devisa dan dampak distribusi manfaat karena lingkupnya terlalu luas untuk penelitian ini dimana penelitian lingkupnya.

\section{Metode Penelitian}

Pada penelitian ini juga menggunakan jenis penelitian kualitatif data yang dikumpulkan tidak berupa angka-angka namun data yang dikumpulkan berasal dari wawancara, catatan lapangan, dokumen pribadi, maupun dokumen resmi yang dimiliki. Menurut Bogdan dan Guba pendekatan kualitatif merupakan prosedur penelitian yang menghasilkan data deskriptif (data yang dikumpulkan berupa katakata, gambar, dan bukan angka). Tujuan dari penelitian yang berbentuk deskriptif menurut M. Nazir untuk membuat deskripsi, gambaran, atau lukisan secara sistematis, factual, dan akurat mengenai fakta-fakta, sifat-sifat, serta hubungannya antar fenomena atau permasalahan yang sedang diselidiki atau diteliti.

Sumber data yang digunakan secara relevan menggunakan bersumber data tertulis, seperti: buku, jurnal ilmiah, skripsi, berita, dan dokumen-dokumen lainnya yang sesuai dengan topik pembahasan dalam penelitian ini mengenai pengembangan desa wisata berbasis pemberdayaan masyarakat di Desa Wisata Kaki Langit. Dalam hal ini penggunaan data-data yang digunakan didalam penelitian mengenai 
pengembangan desa wisata dikunpulkan dari berbagai sumber yang sebelunhya sudah dikumpulan lalu peneliti melakukan analisis dari data tersebut.

\section{Hasil Penelitian}

\section{Pengembangan Desa Wisata Dengan Konsep Pemberdayaan}

Dalam pengembangan desa wisata perlu dipahami kriterianya antara lain: 1) Adanya obyek atau destinasi dan daya tarik: desa memiliki destinasi wisata dan lokasinya berdekatan dengan obyek wisata yang sudah terkenal agar dapat masuk dalam paket perjalanan; 2). Adanya akses fisik (fasilitas) dan pemasaran; 3). Memiliki potensi kemitraan; 4). Adanya antusiasme dan motivasi masyarakat; dan 5). Tersedianya fasilitas umum (Arida and Pujani, 2017).

\section{Daya Tarik Wisatawan}

Wisatawan merupakan target utama pengelola Desa Wisata Kaki Langit, kunjungan wisatawan ke destinasi wisata di Kaki Langit maupun daerah sekitarnya membawa manfaat bagi pelaku usaha masyarakat Padukuhan Mangunan. Wisatawan akan datang berkunjung apabila terdapat potensi wisata yang menarik perhatian untuk datang. Untuk melihat daya tarik wisatawan dapat dilihat dengan dua parameter, yaitu seperti ketersediaan destinasi wisata dan obyek wisata yang berdekatan dengan desa wisata.

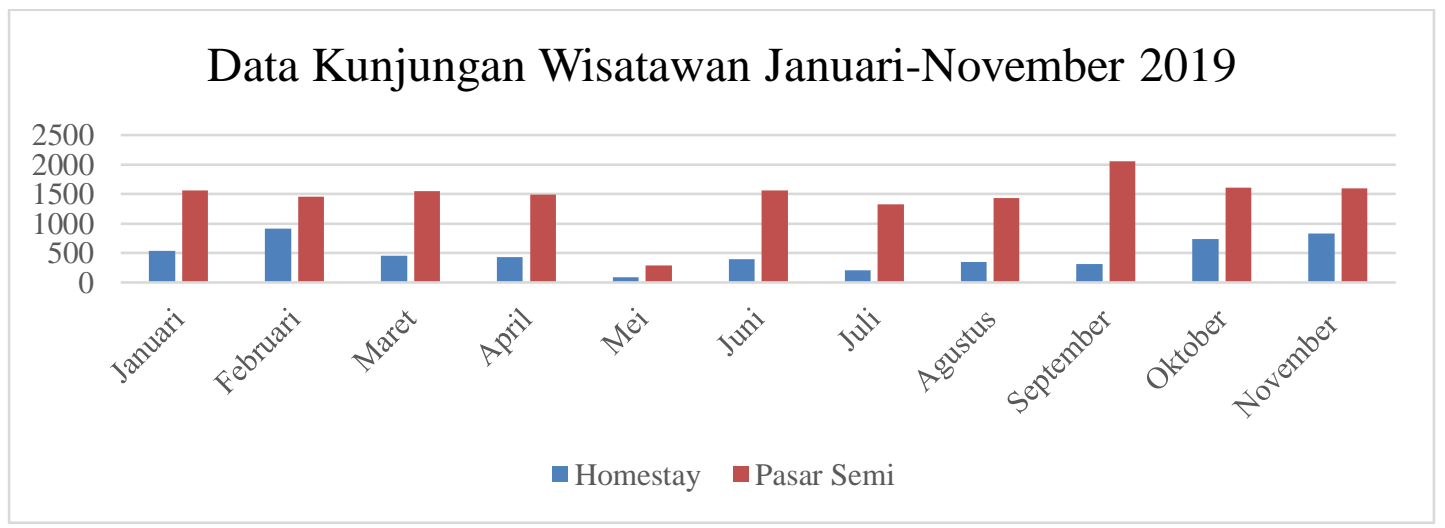

Grafik 1. Kunjungan Wisatawan Desa Wisata Kaki Langit Bulan Januari - November 2019

(Sumber: Pengelola Desa Wisata dan Diolah Peneliti, 2020) 
Kunjungan wisatawan ke Desa Wisata Kaki Langit cukup tinggi, Pasar Kuliner Semi menjadi tempat favorit wisatawan untuk berkunjung. Dari bulan Januari hingga November tingkat kunjungan wisatawan yang menginap cukup tinggi di musim liburan akhir tahun hingga awal tahun mengikuti hari libur wisatawan. Rata-rata kunjungan ke Pasar Kuliner Semi diatas 1500 pengunjung, dan penginapan hampir mencapai 500 wisatawan.

Ketersediaan destinasi wisata yang ada di Desa Wisata Kaki Langit bermacammacam dapat dilihat dari potensi yang ada seperti keindahan alam berupa perbukitan yang masih asri sehingga muncul destinasi seperti kebun buah Mangunan dan hutan pinus. Untuk tradisi dan budaya di Desa Kaki Langit sudah ada sejak lama sebelum adanya desa wisata yang memang sudah menjadi kebiasaan masyarakat Padukuhan Mangunan seperti gejug lesung yang dahulu untuk menandakan saat musim panen padi telah tiba sekarang sebagai tradisi penyambutan wisatawan, selain itu budaya yang ada di Desa Wisata Kaki Langit salah satunya yang menjadi ciri khas yakni konsep homestay dengan menggunakan ciri khas bangunan jawa limasan dan joglo.

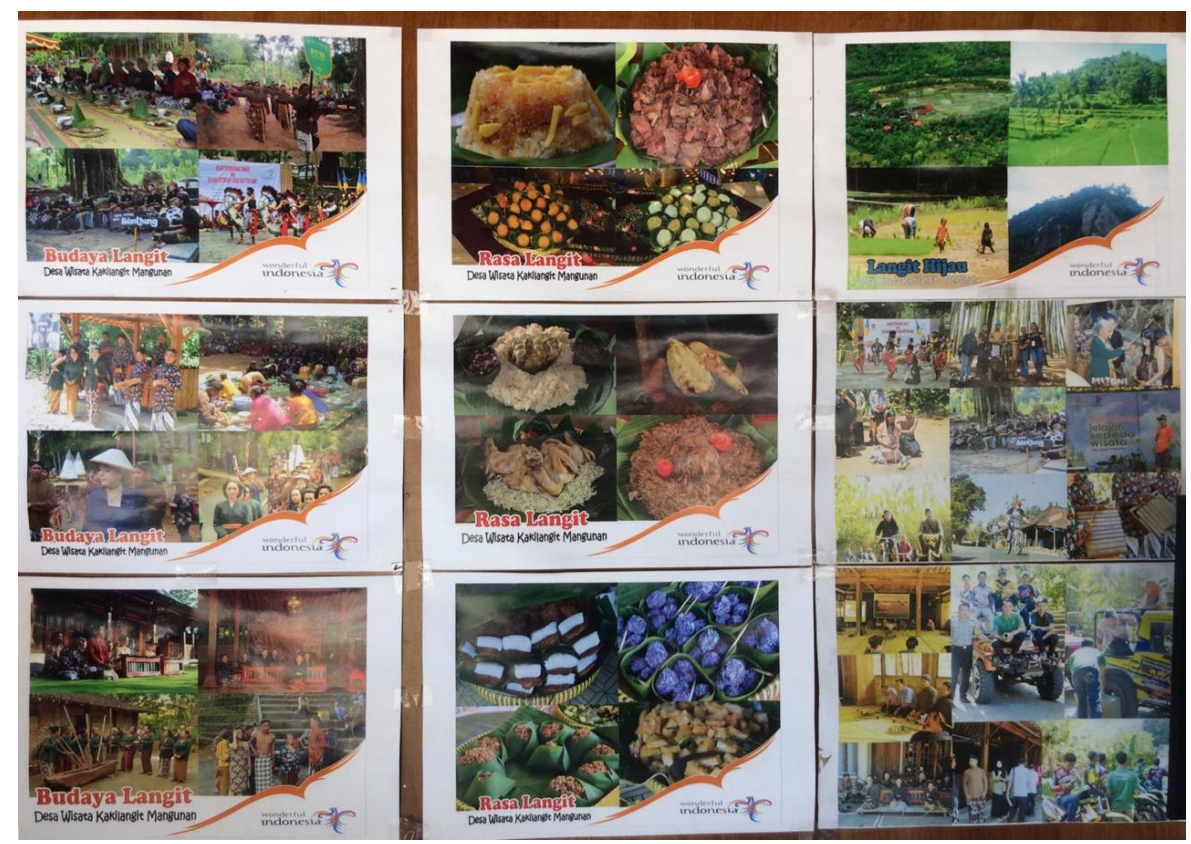

Gambar 1. Potensi Desa Wisata Kaki Langit

Sumber: Dokumentasi Penulis, 2020 
Destinasi wisata lain yang berdekatan dengan Desa Wisata Kaki Langit juga berperan menjadi daya tarik wisatawan untuk datang. Destinasi wisata atau objek wisata yang berdekatan dengan Desa Wisata Kaki Langit. Destinasi yang berdekatan seperti: pusat kerajinan kulit di Manding, pusat kuliner sate kambing di Imogiri, wisata sejarah makam-makam raja di Imogiri, objek wisata Watu Goyang, hutan pinus Mangunan yang sudah terkenal, dan kebun buah Mangunan yang banyak diminati pengunjung untuk menikmati bukit diatas awan. Selain itu pengelola bersaama masyarakat juga menyediakan paket wisata lengkap yang bisa dipilih oleh wisatawan ketika akan berwisata.

Tabel 1. Daftar Paket Wisata

\begin{tabular}{|c|c|c|c|}
\hline No. & Layanan Wisata & Harga & Keterangan \\
\hline 1. & Homestay kamar & @ Rp. 150.000 / kamar & $\begin{array}{l}\text { Non AC, tersedia } 15 \\
\text { kamar }\end{array}$ \\
\hline 2. & Homestay Komunal & @ Rp. 20.000 / orang & $\begin{array}{l}\text { Minimal peserta } 50 \\
\text { orang }\end{array}$ \\
\hline 3. & Outbond & @ Rp. 40.000 / orang & $\begin{array}{l}\text { Minimal peserta } 30 \\
\text { orang }\end{array}$ \\
\hline 4. & Kuliner & $\begin{array}{l}@ \text { Rp. } 10.000-\text { Rp. } 150.000 \\
\text { / orang }\end{array}$ & Sesuai permintaan \\
\hline 5. & Budaya & Menyesuaikan & $\begin{array}{l}\text { Menyesuaikan jenis } \\
\text { budaya }\end{array}$ \\
\hline 6. & Homestay dan Outbond & $\begin{array}{l}@ \text { Rp. } 40.000-\text { Rp. } 45.000 \text { / } \\
\text { orang }\end{array}$ & Permainan 7 - 10 game \\
\hline 7. & $\begin{array}{l}\text { Homestay, Outbond, dan } \\
\text { Kuliner }\end{array}$ & $\begin{array}{l}\text { @ Rp. } 50.000-\text { Rp. } 60.000 \text { / } \\
\text { orang }\end{array}$ & Untuk 10 orang \\
\hline 8. & $\begin{array}{l}\text { Homestay, Outbond, } \\
\text { Kuliner, dan Budaya }\end{array}$ & $\begin{array}{l}@ \text { Rp. } 50.000-\text { Rp. } 60.000 \text { / } \\
\text { orang }\end{array}$ & $\begin{array}{l}\text { Tambahan paket } \\
\text { budaya sebesar } \\
\text { Rp. } 500.000\end{array}$ \\
\hline 9. & $\begin{array}{l}\text { Homestay, Outbound dan } \\
\text { obyek wisata di kawasan } \\
\text { Dlingo - Imogiri }\end{array}$ & $\begin{array}{l}\text { @ Rp. } 50.000-60.000 \text { / } \\
\text { Orang }\end{array}$ & $\begin{array}{l}\text { Harga menyesuaikan } \\
\text { dengan jenis } \\
\text { transportasi yang di } \\
\text { gunakan. }\end{array}$ \\
\hline 10. & Adventure Trial "Track" & @ Rp. 200.000 / Orang & $\begin{array}{l}\text { Peserta } 6 \text { - } 15 \text { Orang. } \\
\text { Fasilitas: Motor, } \\
\text { warepark, untuk track } \\
\text { menggunakan } 2 \\
\text { pmandu dikenkan biaya }\end{array}$ \\
\hline
\end{tabular}


Pengembangan Desa Wisata Berbasis Pemberdayaan Masyarakat Desa Wisata Kaki Langit...

\begin{tabular}{|c|c|c|c|}
\hline 11. & $\begin{array}{l}\text { Paket Adventure Trial } \\
\text { wisata }\end{array}$ & @ Rp. 250.000 / Orang & $\begin{array}{l}3 \text { obyek meliputi Hutan } \\
\text { Pinus, Kebun Buah } \\
\text { Mangunan, Goa Gajah, } \\
\text { durasi } 3 \text { jam. }\end{array}$ \\
\hline 12. & Ubeng Desa & @ Rp. 50.000 / Orang & $\begin{array}{l}\text { Peserta minimal } 10 \\
\text { orang, biaya pemandu } \\
\text { Rp. } 100.000 / 10 \text { jam. } \\
\text { Mengunjungi potensi di } \\
\text { Deswita Kaki Langit. }\end{array}$ \\
\hline 13. & $\begin{array}{l}\text { Hunting Fotografi Kera } \\
\text { Ekor Panjang dan Elang } \\
\text { Jawa }\end{array}$ & @ Rp. 50.000 / Orang & $\begin{array}{l}\text { Minimal peserta } 10 \\
\text { orang, biaya pemandu } \\
\text { Rp. } 100.000 \text {. fasilitas } \\
\text { wedangan dan snack keci }\end{array}$ \\
\hline 14. & $\begin{array}{l}\text { Belajar Bubut Kayu dan } \\
\text { Souvenir }\end{array}$ & @ Rp. 50.000 / Orang & $\begin{array}{l}\text { Durasi } 1 \text { jam maksimal } \\
\text { peserta } 15 \text { orang, } \\
\text { mendapatkan } \\
\text { gantungan kunci atau } \\
\text { souvenir dari Desa } \\
\text { Wisata. }\end{array}$ \\
\hline 15. & $\begin{array}{l}\text { Belajar membuat Rumah } \\
\text { Limasan Replika Rumah } \\
\text { Limasan }\end{array}$ & @ Rp. 15.000 / Orang & $\begin{array}{l}\text { Maksimal peserta } 20 \\
\text { orang. Durasi } 1 \text { jam. } \\
\text { Fasilitas dokumentasi } \\
\text { dan snack kecil. }\end{array}$ \\
\hline
\end{tabular}

Sumber: Pengelola, 2020

Daftar paket wisata yang disediakan pengelola sebagai upaya untuk menarik wisatawan dan membuat wisatawan untuk tidak hanya menginap namun juga banyak aktivitas lain yang bisa dilakukan selama di Desa Wisata Kaki Langit. Sehingga wisatawan dapat menikmati dengan leluasa dan datang kembali berkunjung ke Desa Wisata Kaki Langit.

\section{Akses dan Kemitraan}

Semakin berkembangnya banyak desa wisata di Desa Mangunan seperti Desa Wisata Kaki Langit yang berada di Padukuhan Mangunan menuntut kemudahan akses berupa infrastruktur jalan ataupun jaringan telekomunikasi agar wisatawan yang berkunjung semakin banyak. Kemudahan akses sebagai salah satu faktor pendukung untuk menarik kunjungan wisatawan. Jika destinasi memiliki akses atau infrastruktur yang memadai yang mudah maka wisatawan tidak akan ragu untuk 
datang. Selain itu bisa juga melibatkan pihak lain atau mitra untuk membantu proses pengembangan desa wisata. Akses menuju Desa Wisata Kaki Langit semakin mudah, dahulu setelah mulai didirikan memang jalan masih sempit, berlubang, jika malam jalan gelap kurangnya penerangan, dan jaringan telefon belum sepenuhnya lancar. Hal ini dikarenakan letak Desa Kaki Langit yang berada di perbukitan. Bahkan jika musim penghujan tiba jalan rawan longsor.

Selain adanya kemudahan akses perlu juga dalam pengembangan desa wisata untuk menjalin kemitraan dengan pihak lain. Mulai terkenalnya Desa Wisata Kaki Langit karena adanya jalin kemitraan dengan salah satu organisasi pariwisata yang aktif dalam media sosial yakni Generasi Pesona Indonesia (GENPI) region Jogja dimulai pada tahun 2017 yang difasilitasi oleh Dinas Pariwisata Provinsi Daerah Istimewa Yogyakarta (DIY). Genpi Jogja aktif membagikan dokumentasi melalui media sosial terkait kegiatan wisata yang ada di Desa Wisata Kaki Langit.

Kementerian Pariwisata Republik Indonesia juga pernah memfasilitasi desa wisata dengan salah satu aplikasi pesan penginapan secara online yakni booking.com, namun setelah dievaluasi hal ini tidak berjalan. Faktor keterbatasan kemampuan menggunakan aplikasi merupakan faktor utama kendala yang dialami masyarakat yang memiliki penginapan. Sampai dengan saat ini masyarakat mengandalkan aplikasi google maps yang dilengkapi nomer telefon untuk memudahkan wisatawan memperoleh lokasi dan pemesanan melalui nomer telefon.

\section{Partisipasi Masyarakat}

Desa Wisata Kaki Langit yang pengembangannya menggunakan konsep pemberdayaan masyarakat dan dikelola langsung oleh masyarakat Padukuhan Mangunan dipastikan membutuhkan partisipasi langsung dari masyarakatnya. Tingkat keikutsertaan masyarakat dalam pengembangan Desa Wisata Kaki Langit cukup tinggi karena pengelola membentuk unit kegiatan atau usaha yang berjumlah delapan untuk dikembangkan dan selanjutnya dikelola secara langsung oleh 
masyarakat Padukuhan Mangunan. Masyarakat diberikan keleluasaan untuk mengembangkan unit kegiatan tersebut, karena hanya masyarakat Padukuhan Mangunan yang dapat mengembangkan dan proses pengelolaanya.

Tabel 2. Wadah Pemberdayaan Masyarakat

\begin{tabular}{|c|l|l|}
\hline No. & Unit Kegiatan & Kegiatan \\
\hline 1. & Atap Langit & Homestay (penginapan) \\
\hline 2. & Rasa Langit & Kuliner \\
\hline 3. & Budaya Langit & Atraksi Kebudayaan \\
\hline 4. & Langit Terjal & Akomodasi Wisata \\
\hline 5. & Langit Ilalang & Outbond \\
\hline 6. & Karya Langit & Kerajinan \\
\hline 7. & Langit Cerdas & Edukasi \\
\hline
\end{tabular}

Sumber: Pengelola, 2020

Pengelola Desa Wisata Kaki Langit membentuk delapan wadah untuk mendorong masyarakat Padukuhan Mangunan ikut dalam kegiatan pengembangan pariswisata. Pembentukan tersebut agar mempermudah masyarakat untuk ikut serta sesuai dengan bidang yang dimiliki. Atap Langit dan Rasa Langit unit kegiatan yang paling diminati masyarakat karena masayarakat Padukuhan Mangunan memiliki potensi untuk mengelolanya, namun unit lain juga tetap banyak peminatnya. Namun masih ada unit kegiatan yang belum berkembang seperti langit ilalang, karya langit, dan langit cerdas. 


\section{Fasilitas Umum}

Kegiatan desa wisata tentu saja tidak bisa lepas dengan tersedianya fasilitas umum untuk mendukung dan mendorong segala kegiatan yang ada didalamnya. Kelengkapan fasilitas dapat mempermudah wisatawan yang berkunjung ke destinasi tersebut. Fasilitas yang lengkap membuat wisatawan tidak akan ragu untuk berkunjung. Ketersediaan fasilitas umum pendukung sangat penting untuk mendukung kegiatan pengembangan desa wisata. Saat ini fasilitas yang mendukung cukup tersedia mulai adanya tempat ibadah, lahan parkir, dapur umum, sekretariat sebagai pusat informasi dan lainnya. Pihak pengelola menyediakan fasilitas pendukung agar wisatawan nyaman ketika berkunjung ke Desa Wisata Kaki Langit.

\section{Dampak Perekonomian Adanya Desa Wisata}

Kegiatan pengembangan Desa Wisata Kaki Langit yang menggunakan konsep pemberdayaan masyarakat dengan mengikutsertakan masyarakat sekitar desa wisata dalam pengembangan desa wisata. Adanya partisipasi masyarakat secara langsung dalam pengembangannya, mendatangkan manfaat dampak perekonomian yang masyarakat rasakan.

Mayoritas mata pencaharian masyarakat Padukuhan Mangunan sebelum adanya desa wisata sebagai petani dan buruh. Masyarakat hanya mengandalkan hasil pendapatan dari profesi utamanya tersebut. Meski sebenarnya masyarakat memiliki potensi yang dimiliki untuk dikembangkan. Setelah adanya dorongan dari tokoh masyarakat terbentuklah secara bertahap desa wisata. semakin berkembangnya desa wisata minat masyarakat mulai tinggi untuk ikut berpartisipasi untuk mengembangan potensi yang dimiliki. Adanya desa wisata kini masyarakat memiliki pendapatan tambahan sehingga tingkat perekonomian masyarakat Padukuhan Mangunan meningkat. 


\section{Pendapatan Masyarakat}

Kegiatan desa wisata di Padukuhan Mangunan secara langsung maupun tidak langsung akan berdampak terhadap pendapatan masyarakat. Sebelum adanya desa wisata di Padukuhan Mangunan mayoritas masyarakat setempat mengandalkan pendapatan sehari-hari yang pendapatannya tidak menentu dari profesi mereka sebagai bertani, beternak dan wirausaha. Padukuhan Manguna yang menjadi tempat tinggal mereka dan mereka sendiri memiliki potensi yang dapat dikembangkan untuk menambah penghasilan sehari-hari. Namun setelah potensi di Padukuhan Mangunan perlahan dapat dikembangkan tingkat pendapatan masyarakat meningkat penghasilan mereka bertambah.

Adanya Desa Wisata memberikan dampak positif terhadap perekonomian lokal. Pendapatan masyarakat Padukuhan Mangunan bertambah adanya partisipasi masyarakat untuk ikut serta kegiatan desa wisata. Masyarakat yang memiliki potensi rumah lebih dari satu membuka penginapan, masyarakat yang memiliki kemampuan memasak masakan tradisional membuka warung makan, pemuda dilibatkan kegiatan jelajah alam. Kegiatan tersebut menambah pemasukan tambahan disamping pekerjaan utama masyarakat.

\section{Kesempatan Kerja}

Desa Wisata Kaki Langit yang menggunakan konsep pemberdayaan masyarakat tentu saja menggerakan elemen masyarakat secara langsung. Dahulu sebagian masyarakat hanya bergantung di bidang pertanian bahkan masih ada yang belum mendapatkan pekerjaan namun adanya desa wisata masyarakat mendapat kesempatan kerja baru. Hal ini secara langsung membuka kesempatan kerja baru bagi masyarakat. Masyarakat mendapatkan pekerjaan baru seperti mengelola penginapan, warung makan, pasar kuliner, lahan parkir, outbond, dan masih banyak lagi. Kegiatan tersebut membutuhkan tenaga dalam kegiatannya sehingga membuka kesempatan baru bagi masyarakat Padukuhan Mangunan. 


\section{Kepemilikan dan Kontrol Ekonomi}

Desa wisata yang salah satu upaya untuk pengembangan pariwisata lokal yang mengikutsertakan masyarakat secara langsung. Hakikatnya jika mengukitsertakan masyarakat dalam pembangunannya maka masyarakat berhak memiliki secara langsung juga dan mengelolanya. Selain itu masyarakat juga diikutsertakan dalam kegiatan bagi hasil sebagai salah satu upaya kontrol ekonomi dan transparansi. Wadah kegiatan yang dibentuk pengelola seperti penginapan, warung makan, pusat oleh-oleh, pasar kuliner, usaha outbond seluruhnya dimiliki oleh masyarakat. Dalam pembagian hasil usaha juga dilakukan pengelola bersama masyarakat. Terdapat peraturan desa bahwasanya tanah kas desa dapat dimanfaatkan masyarakat untuk usaha dengan menyetor kas desa sebesar 10 persen dari pendapatan.

\section{Pembangunan}

Kegiatan pariwisata Desa Wisata Kaki Langit di Padukuhan Mangunan yang sampai sekarang semakin berkembang dapat menjadi faktor pemicu terhadap adanya kemajuan pengembangan sarana infrastruktur pendukung. Awalnya sebelum desa wisata berkembang fasilitas di Padukuhan Mangunan bisa dibilang terbatas seperti jalan masih banyak yang rusak, sarana pendukung belum memadai, jaringan telekomunikasi belum sepenuhnya baik. Namun kini yang dirasakan masyarakat sekarang sudah berbeda.

Perkembangan desa wisata yang membuat masayarakat luar Padukuhan Mangunan datang berkunjung menjadi faktor untuk terus dilakukannya pembangunan sarana dan prasana agar masyarakat yang ingin berkunjung merasa nyaman. Jalanan utama menuju sampai Padukuhan Mangunan sudah teraspal dengan baik dilengkapi lampu penerangan dan penunjuk arah walau belum seluruhnya, pembangunan jalan masuk padukuhan juga diperbaiki sebagai akses menuju tempat wisata dan penginapan, lahan parkir, toilet umum, pasar kuliner juga dibangun. 
Pengembangan Desa Wisata Berbasis Pemberdayaan Masyarakat Desa Wisata Kaki Langit...

\section{Pendapatan Pemerintah}

Pariwisata lokal yang berkembang di Desa Wisata Kaki Langit yang berawal dari desa rintisan namun sekarang desa wisata mandiri karena semakin meningkatnya pemasukan dan semakin dikenal oleh wisatawan. Upaya untuk mengelola potensi desa dimiliki dan meningkatkan pendapatan desa sudah lama dirintis oleh pemerintah dan masyarakat desa Mangunan, Kecamatan Dlingo, Kabupaten Bantul melalui pemanfaatan sektor pariwisata. Potensi yang sudah ada sejak dahulu sangat terbuka untuk dimanfaatkan karena Desa Mangunan khususnya Padukuhan Mangunan memiliki objek wisata dan kegiatan yang dapat dikelola masyarakat. Pemerintah desa juga memiliki tanah kas desa yang dapat dimanfaatkan masyarakat untuk menyelenggarakan kegiatan pariwisata. Untuk mendukung adanya peningkatan pendapatan asli desa, pemerintah bersama pengelola wisata di lingkup Desa Mangunan beserta tokoh masyarakat sebagai perwakilan masyarakat membuat suatu peraturan desa (perdes) tentang retribusi wisata. Pada tahun 2017 dibuatlah Perdes Mangunan Nomor 3 tahun 2017 tentang Retribusi Wisata. didalam perdes tersebut dijelaskan bahwa masyarakat atau kelompok usaha wisata dikenakan retribusi sebesar 20 persen dari total pendapatan tiap tahun apabila objek wisata atau kegiatan wisata yang dilakukan oleh kelompok wisata atau masyarakat menempati tanah kas milik desa, sedangkan milik pribadi dikenakan 10 persen.

Tabel 3. Jumlah PADes dari Desa Wisata Kaki Langit

\begin{tabular}{|l|l|l|}
\hline No. & Tahun & Jumlah \\
\hline 1. & 2017 & Rp. 750.000 \\
\hline 2. & 2018 & Rp. 1.580 .000 \\
\hline 3. & 2019 & Rp. 2.080 .000 \\
\hline & Total & Rp. 4.410 .000 \\
\hline
\end{tabular}

Sumber: Pemerintah Desa Mangunan, 2020 
Desa Wisata Kaki Langit sejak tahun 2017 sudah dikenakan retribusi oleh Pemerintah Desa Mangunan karena sudah berkembang dan berhasil mendatangkan banyak wisatawan. Tahun 2017 menyetor Rp. 750.000, lalu pada tahun 2018 meningkat menjadi Rp. 1.580.000, dan pada tahun 2019 kembali menungkat menjadi Rp. 2.080.000 dengan selama 3 tahun Desa Wisat Kaki Langit sudag memberikan retrtibusi pendapatan ke Desa Mangunan sebanyak Rp. 4.410.000 dari tahun ke tahun terus meningkat.

\section{Simpulan dan Saran}

Kegiatan pengembangan desa wisata sebagai salah satu upaya untuk memanfaatkan potensi desa yang dimiliki untuk dikembangkan. Desa wisata mampu mempertahankan keadaan budaya dan sosial yang dimiliki, hal tersebut dapat menjadi kegiatan pelestarian budaya agar tidak hilang dan tetap dilestarikan. Pengembangan wisata berbasis lokal dengan mengembangkan desa wisata yang mengedepankan keadaan budaya lokal dan tradisi mampu menarik orang datang untuk berkunjung.

Pengembangan desa wisata yang melibatkan masyarakat sekitar desa wisata secara langsung mampu mengubah keadaan masyarakat Padukuhan Mangunan jauh lebih baik dari sebelumnya. Mayoritas masyarakat yang dahulunya hanya mengandalkan sektor pertanian dan pekerjaan sampingan yang tidak menentu, melalui desa wisata mereka dapat berperan aktif memanfaatkan potensi lain yang dimiliki alhasil mendapat pendapatan baru. Selain itu masyarakat juga mampu membuka kesempatan kerja baru. Pembangunan di sekitar desa wisata juga terus meningkat untuk mendukung kegiatan desa wisata. Hal ini juga dirasakan oleh pemerintah desa yang mendapat pemasukan baru dari kegiatan wisata

Konsep pengembangan pariwisata lokal melalui desa wisata untuk mengembangkan potensi masyarakat tidak akan berjalan baik apabila partisipasi masyarakat belum maksimal. Oleh karena itu perlunya perencanaan yang matang 
dan pelibatan masyarakat secara langsung juga dalam perencanaan bersama pemerintah dan kelompok pengelola wisata serta harus terus dilakukan peningkatan keahlian masyarakat dalam mengelola wisata. Maka dari itu terdapat tiga saran untuk terus meningkatkan dan mendukung kegiatan pengembangan desa wisata, yakni 1) Adanya partisipasi masyarakat yang semakin banyak akan semakin baik dan mendatangkan manfaat untuk masyarakat sendiri, 2) Adanya kegiatan peningkatan kemampuan dan keahlian masyarakat khususnya bidang teknologi akan mempermudah dan membantu masyarakat mengikuti perkembangan zaman, dan 3) Masyarakat dan pengelola untuk terus berinovasi mengembangkan wisata yang berkelanjutan dan tetap mengedepankan kelestarian alam, budaya, dan tradisi sebagai daya tarik utama desa wisata.

\section{Ucapan Terimakasih}

Ucapan terimakasih tak lupa kami haturkan kepada Allah SWT Tuhan Yang Maha Esa yang telah memberikan kelancaran dalam proses penelitian hingga penulisan penelitian ini, terimaksih juga kami haturkan kepada masyarakat Padukuhan Mangunan dan Pemerintah Desa Mangunan yang ikut membantu dalam pengambilan data penelitian ini semoga kedepannya Desa Wisata Kaki Langit terus berkembang dan berprestasi dibidang pariwisata untuk melestarikan tradisi dan budaya serta mensejahterakan masyarakat sekitar.

\section{Daftar Pustaka}

Arida, I. N. S. and Pujani, L. K. 2017 `Kajian Penyusunan Kriteria-Kriteria Desa Wisata Sebagai Instrumen Dasar Pengembangan Desawisata', Jurnal Analisis Pariwisata, 17(1), pp. 1-9.

Dwiridhotjahjono, J., Wibowo, P. and Nuryananda, P. F. 2019 'Peran Masyarakat dalam Pengembangan Desa Wisata Berbasis Masyarakat', Jurnal Master Pariwisata (JUMPA), 6, pp. 241-266.

Fandi, K., Zauhar, S. and Hermawan 2012 'Kemitraan Pengelolaan Sektor Pariwisata', Jurnal Administrasi Publik (JAP), 1(1), pp. 47-55. 
Hermawan, H. 2016 'Dampak Pengembangan Desa Wisata Nglanggeran Terhadap Ekonomi Masyarakat Lokal', Jurnal Pariwisata, 3(2), pp. 105-117.

Indardi 2016 Komunikasi pemberdayaan masyarakat. Edited by W. Nadeak et al. Bandung: UNPAD Press.

Kristiana and Theodora, S. 2016 'Strategi Upaya Pengembangan Pariwisata Berkelanjutan Agrowisata Berbasis Masyarakat Kampung Domba Terpadu Juhut, Provinsi Banten', Jurnal Ilmiah Widya, 3(3), pp. 1-7.

Muhammad Farid Ma'ruf, B. and Kurniawan, R. P. A. G. P. 2017 `Desa Wisata: Sebuah Upaya Mengembangkan Potensi Desa dan Meningkatkan Pendapatan Asli Desa (Studi Pada Desa Wisata Bejiharjo Kecamatan Karangmojo Kabupaten Gunungkidul)', Jurnal Dinamika Governance, 7(Nomor 2), pp. 192-202.

Zaenuri, M. 2018 Tata Kelola Pariwisata Bencana Berbasis Collaborative Governance, Konsep, Analisis, dan Pemodelan (1st ed.). Yogyakarta: Explore.

\section{Profil Penulis}

Anggit Kurnia Prihasta, S.IP adalah mahasiswa lulusan Ilmu Pemerintahan, Fakultas Ilmu Sosial dan Ilmu Politik, Universitas Muhammadiyah Yogyakarta (UMY). Ia menyelesaikan pendidikan S1 di Program Studi Ilmu Pemerintahan UMY.

Dr. Suswanta, M.Si adalah dosen Program Studi Ilmu Pemerintahan, Fakultas Ilmu Sosial dan Ilmu Politik, Universitas Muhammadiyah Yogyakarta (UMY). Beliau menyelesaikan pendidikan S1 di Jurusan Ilmu Pemerintahan Universitas Gadjah Mada, S2 dan S3 di Jurusan Ilmu Politik UGM. Ia pernah menulis artikel pada jurnal ilmiah yang berkaitan dengan collaborative governance, good university governance \& tindakan politik kyai. 